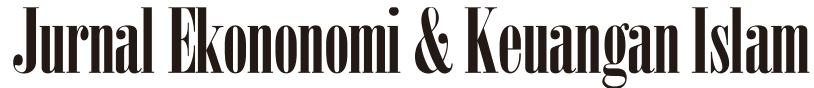

\section{Factors determining behavioral intentions to use Islamic crowdfunding platform in times of Covid-19 in Indonesia: Evidence from TAM approach}

\author{
Sulaeman \\ Faculty of Economic and Business, Universitas Airlangga, Surabaya, Indonesia
}

\begin{abstract}
Article History
Received : 22 November 2020

Revised : 27 December 2020

Accepted : 30 December 2020

Published : 11 January 2021
\end{abstract}

Keywords:

Indonesia, Covid-19, Islamic

FinTech, Islamic Crowdfunding,

TAM approach

DOI:

https://doi.org/10.20885/JEKI.vol 7.iss1.art3

JEL Clasification:

G20, G23, G30

Corresponding author:

Sulaeman-2019@feb.unair.ac.id

Author's email:

sulaeman.sunda@gmail.com

Paper type:

Research paper

Cite this article:

Sulaeman. (2021). Factors

determining behavioral intentions to

use Islamic crowdfunding platform

in times of Covid-19 in Indonesia:

Evidence from TAM approach.

Jurnal Ekonomi dan Keuangan Islam,

7(1), 31-44.

https://doi.org/10.20885/JEKI.vol

7.iss1.art3

\begin{abstract}
Purpose - The research paper aims to test empirically the behavioral intention of crowdfunders to use the Islamic crowdfunding platform model based on the theory of the Technology Acceptance Model (TAM).

Methodology - The study used primary data that are collected by using the online survey questionnaires and then the analysis is conducted using partial least squares (PLS).

Findings - The empirical evidence shows that the perceived usefulness (PU) has a significant positive impact on the behavioral intention (BI) of crowdfunders to use Islamic crowdfunding platform. Furthermore, the perceived ease of use (PEOU) also has a significant and positive relationship as well as direct effect with perceived usefulness (PU) of crowdfunders to use the online platforms. Meanwhile, that perceived ease of use (PEOU) has an insignificant relationship with the behavioral intention (BI) of crowdfunders to use the Islamic crowdfunding platform during the Covid-19 pandemic in Indonesia.
\end{abstract}

Practical implications - The present study has implications for Islamic FinTech companies to provide investment platforms for crowdfunders and financial services for micro small and medium-sized enterprises (MSMEs) during the pandemic of Covid-19.

Originality - The finding of this study will contribute to the existing literature in the areas of Islamic FinTech especially on the factors influencing behavioral intentions to use the Islamic crowdfunding platform in times of Covid-19 in Indonesia.

\section{Introduction}

As a global pandemic today, the problematic phenomenon of Coronavirus Disease 2019 or Covid19 (the current term of the virus) has been becoming a disease issue worldwide (Chamani et al, 2020). The Covid-19 is not only medical problem but also becomes economic problem for many countries in the world (Burhan, 2020). According to Sri Mulyani Indrawati, Minister of Finance of Indonesia, the current crisis caused by the Covid-19 pandemic was far more complex than the 1997-1998 and 2008-2009 crises (Victoria, 2020). 
In line with that, the Covid-19 pandemic is going to bring a more severe impact on MSMEs than other sectors in Indonesia. Based on the data from the Ministry of Cooperatives and Small and Medium Enterprises (Kementerian Koperasi \& UKM, 2018), the number of MSMEs is approximately 64 million which absorbs more than 117 million workers or $97 \%$ of the total workforce. According to Haider \& Khan (2020), MSMEs are in urgent need of funds for survival if the situation continues for a long period of time. Most of the MSMEs are battling for survival as it has become really difficult for them to bear the operating expenses like paying salary, rent, and others. Furthermore, many scholars, practitioners, academicians, and civil society have been discussing through webinar (online discussion) for seeking solutions to overcome. They suggested that optimizing the role of Islamic financial technology (Islamic FinTech) is one of the effective solutions for any problems in MSMEs, apart from banking (Mukhlisin et al., 2020).

On the other hand, as the largest Muslim population in the world, the market share of Islamic FinTech is huge because Indonesia has a strong power compared to other countries in Southeast Asia Region (Aulia et al., 2020). Indonesia also has been increasing rapidly in using the online platform alongside the increasing number of internet users in Indonesia. Based on the report from Internet World Stats (2020), currently internet users are more than half of the total population in Indonesia (around 171.3 million users). This is because the online platform can support many people by taking advantage of the online aspects such as investment and donation activities. The crowdfunders contribute and donate as well as invest to crowdfunding will get an advantage e.g. reducing the cost of transactions quickly and easily by using Quick Respond (QR) code services to make it easier (Hudaefi et al., 2020), and also the ability to attract the same emotional interest of users (Suhaili \& Palil, 2016).

Furthermore, the authority institutions in Indonesia have issued several regulations to support and regulate Islamic FinTech, including the regulations (fatwa) of the National Shariah Council of the Indonesian Ulema Council Number 117/DSN-MUI/II/2018 on the compliance of the information technology-based financing services with the Shariah principles (Dewan Syariah Nasional, 2018), Bank Indonesia Regulation Number 19/12/PBI/2017 on the Implementation of Financial Technology (Bank Indonesia, 2017), and the regulation of the Indonesian Financial Services Authority Number 77/POJK.01/2016 on the information technology-based lending and borrowing services (Otoritas Jasa Keuangan, 2016). Following that, the development of Islamic FinTech firms is increasing in Indonesia. There are several existing Islamic FinTech companies in Indonesia, which are: Ammana, Investree, Dana Syariah, WakApp, Tamasia, eFunding, Maslahat Kita, Goolive, Kandang.in, Danakoo Syariah, IjabQobul, InvesProperti, Ethiscrowd, and Angsur (Majid, 2018).

Based on the above explanation, I confirm that Indonesia has great potential to fight the economic impact of Covid-19 particularly on MSMEs by optimizing the role of Islamic FinTech especially the Islamic crowdfunding platform as an intermediary between Muslim crowdfunders (Investors) and MSMEs to provide Islamic financial services. Therefore, this study aims to test empirically the behavioral intention of crowdfunders to use the Islamic crowdfunding model based on the theory of the Technology Acceptance Model (TAM) proposed by Davis (1989). The theory has been used by a number of researchers including Ratri (2016), Riza \& Hafizi (2019), Thaker (2018), Huei et al. (2018), Darmansyah et al. (2020), Tamimi and Ahmad (2020). However, a number of researchers only focused on the user's perception of behavioral intention to use technological innovation services and products such as mobile banking. Differently, this study will examine the intention of Muslim crowdfunders (investors) to adopt the online platform for investment activities especially using the existing Islamic crowdfunding platform in times of Covid-19 outbreaks in Indonesia. Moreover, the present study is also expected to contribute to the existing literature especially on the factors influencing the adoption of Islamic crowdfunding platform in Indonesia.

\section{Literature Review}

\section{Islamic Crowdfunding}

In general, crowdfunding is a part of financial technology (FinTech) innovation that provides financing services for individuals and businesses (Harahap et al., 2017). The crowdfunding is an 
online platform which is used for a process of collection of funds (in a small amount) from the individuals or institutional crowdfunders by using the website platform for a specified project, business venture, or social project (Belleflamme et al., 2014; Dresner, 2014; Mollick, 2014; Suhaili \& Palil, 2016; Thaker, 2018).

Meanwhile, Achsien \& Purnamasari (2016) defined that crowdfunding in Islamic perspectives is a process to collect amounts of money from a huge number of individuals or organizations via the online platform complied with shariah principles, The platform aims to fund the business projects, personal loans, and other needs. There are some basic features which are distinguishing the Islamic crowdfunding platform from the conventional one, namely: (1) halal projects, (2) free from usury (riba), gambling (maysir), speculation (gharar), and (3) the existence of Shariah supervisory board (Achsien \& Purnamasari, 2016). Additionally, the requirements of the Islamic crowdfunding model involve project initiators (e.g. individuals, organizations, and businesses); potential funders (PF); crowdfunding operators (CFO); and the Shariah supervisory board ( Marzban et al., 2014).

Islamic crowdfunding also can be divided into four types. First, it is donation-based crowdfundingwhich is made for supporting the social projects and usually managed by NGOs. The contributors, who participate the social projects, do not recieve any benefits from their donations. Second, reward-based crowdfunding, this type is the collection of funds from many crowdfunders and they will receive some tangible rewards as a token appreciation for their participations in social projects. Third, debt-based or lending-based crowdfunding, this type allows a number of investors who invest their funds for providing loans tostartups or small enterprises in order to support their ventures. Last, equity-based crowdfunding, this type is when a number of investors offer equity funds in the business venture for supporting startups or small enterprises. The investors will receive the percentage of profit-sharing on their investment (Harahap et al., 2017; Hidajat, 2019; Marzban et al., 2014; Ramos, 2015; Sangwan et al.,2019; Thaker, 2018).

In Islamic crowdfunding, there are some advantages in this platform, for instance, the online platform provides an alternative source of funding for micro enterpreneurs, SMEs, companies and so on. The Islamic crowdfunding platform attracts the emotional interest of crowdfunders to invest, contribute or donate regardless their geography and it is also a low-cost access of funding (Suhaili \& Palil, 2016). Furthermore, Islamic crowdfunding platform provides an opportunity for investors, donors, and entrepreneurs for supporting the socio-economic development of Muslim entrepreneurs or MSMEs in Islamic countries (Marzban et al., 2014).

\section{Technology Acceptance Model (TAM)}

TAM was introduced by Davis (1989) which adapted from the Theory of Reasoned Action (TRA). TAM describes the technology acceptance in an organization by individuals (Davis, 1989). TAM also explains the individual's intention to use new information technology (Chen et al., 2011). The determinant of TAM was in the two most important factors of intention to adopt new information technology, which are perceived usefulness (PU) and perceived ease of use (PEOU) (Davis, 1989). Davis (1989) explained that PU is defined as the degree to which an individual believes that the usage of technology would improve his or her performance. Meanwhile, PEOU is defined as the degree to which an individual believes that the usage of particular technology would be free from effort (Davis, 1989). Further, PEOU has both a direct effect and an indirect effect on the adoption intention through perceived usefulness. Thus, PEOU affects both PU and individual attitudes (Davis, 1993; Venkatesh \& Davis, 2000).

A number of researchers have used TAM approach as a model for understanding new technological acceptance. For instance, Thaker (2018) identified the potential factors that influence crowdfunders' intention to adopt the crowdfunding-waqf model (CWM) in Malaysia. The results show that the PEOU and PU have a significant and positive effect on the intention to adopt CWM. Furthermore, PEOU has a positive and indirect effect on the intention to use CWM via perceived usefulness. Huei et al. (2018) identified PEOU and PU have a significant and positive effect on the intention to adopt FinTech's products and services in Malaysia. 
In line with Riza \& Hafizi (2019), it indentified that the relationship between PU and BI, PEOU and BI, PEOU and PU have a positive and significant effect on the use of Islamic mobile banking application in the era of industry 4.0. Another research using TAM model, Tamimi \& Ahmad (2020) have conducted empirical studies to examine the understanding of technological adoption using the TAM approach. They commended TAM to be a beneficial model to understand and explain a user's intention to adopt new technology.

\section{Hypothesis Development and Conceptual Framework}

The study is designed to test empirically the behavioral intention factors of crowdfunders to use the Islamic crowdfunding platform model based on the TAM approach. Perceived usefulness (PU), perceived ease of use (PEOU), and behavioral intention (BI) are the construct variables in this study. The first construct is PU. PU has a significant and positive effect on the intention to use financial technology products and services such as Huei et al., (2018). PU has a strongly significant impact and important variable to influence attitude, behavior, and intention to accept the new technology (Ratri, 2016). There were six indicator items to measure PU, namely: fast access, performance, productivity, effectiveness, make job easier, useful and helpful (Ratri, 2016; Riza \& Hafizi, 2019).

The second construct is PEOU. PEOU has a significant and positive effect on the intention to use financial technology products and services (Huei et al., 2018). In addition to that, PEOU influences the intention, perceived usefulness, attitude, and actualization of using technology (Davis, 1989). There were six indicator items to measure PEOU including easy to use, controllable, clear and understandable, flexibile, easy to master, and also easy to learn (Ratri, 2016; Riza \& Hafizi, 2019). The last construct is BI to use the Islamic crowdfunding platform. According to Ratri (2016) stated that planned utilization in the future is one of the indicators to the intention of individuals to the actual use of the technology. Therefore, there are three hypotheses of this study, which are:

H1. PU positively affects on BI to use the Islamic crowdfunding platform.

H2. PEOU positively affects on BI to use the Islamic crowdfunding platform.

H3. PEOU positively affects on PU to use the Islamic crowdfunding platform.

The conceptual framework for this study is shown in Figure 1.

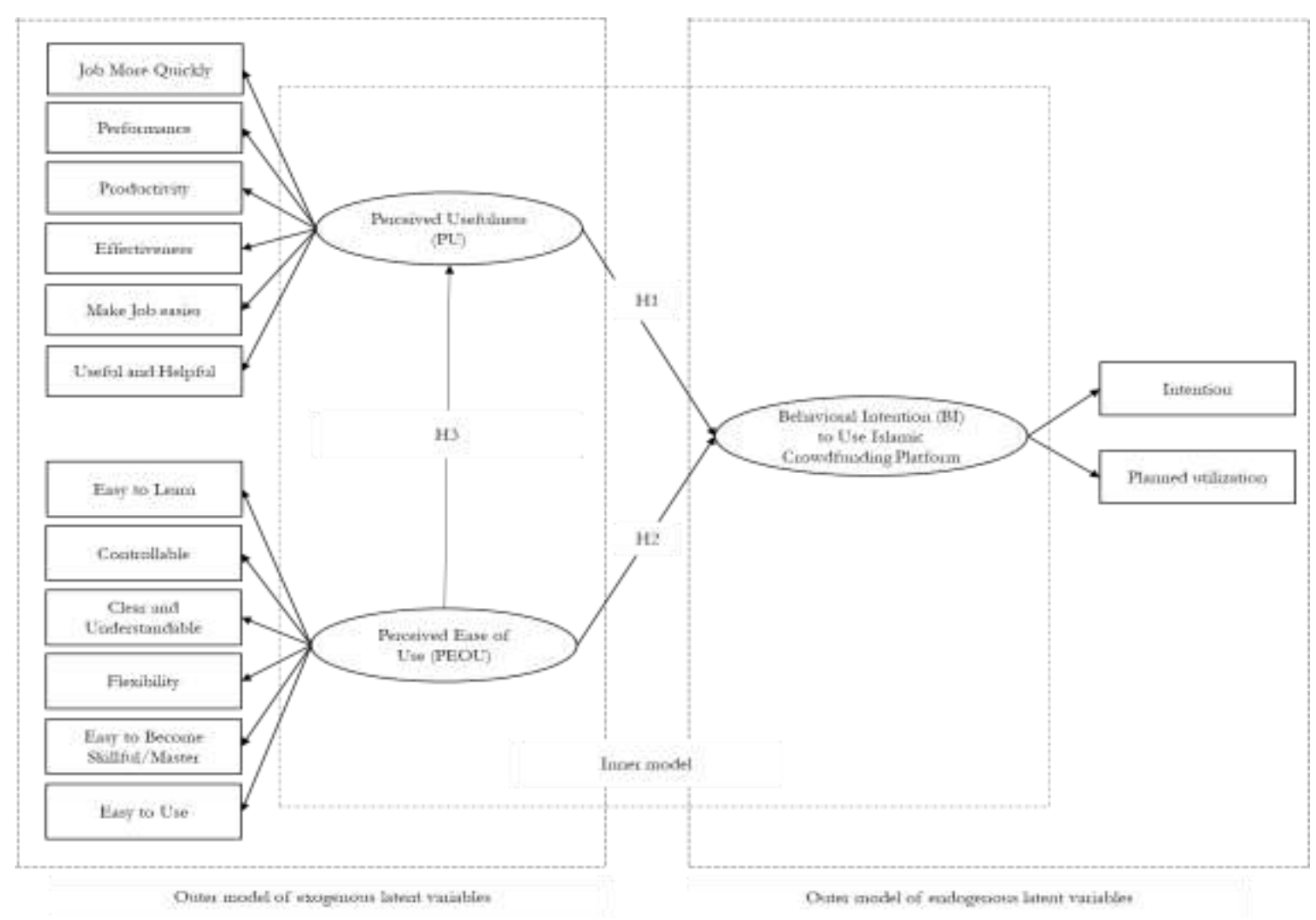

Source: some previous studies

Figure 1. The conceptual framework of the study 


\section{Research Methods}

\section{Research Design}

This study uses the online survey questionnaires to test the factors of the behavioral intention of Muslim crowdfunders to use the Islamic crowdfunding platform. The online questionnaires were designed and adapted from previous researchers and were modified to suit the purpose of this study. The questionnaire was divided into the following two components: respondents' demographics and variable constructs. The questionnaire contains three variable constructs: PU (six items), PEOU (six items), and BI (four items) as shown in Appendix 1. In total, 16 question statements were measured by a five-point Likert scale from strongly disagree (1) to strongly agree (5).

\section{Data and Sample}

This study uses primary data collected from the respondents who can access the Islamic FinTech platform particularly the existing Islamic crowdfunding platform in Indonesia such as Ammana, Dana Syariah, Investree, etc. The sample in this study was the respondents who can access Islamic crowdfunding platform with a smartphone in the various demographics, geographic areas and religions in Indonesia. The online survey questionnaire was distributed on May 2020. After data screening, the final sample size used in the study was 100 responses. A small number of respondents who participated in this study may due to the time constraints and the disinclination of respondents to participate in the survey. However, according to Raza et al. (2019), for the structural equation model technique, a sample size of 100 and minimum three items per variable is enough for convergence.

\section{Data Analysis Method}

The data analysis used partial least squares (PLS) and followed the guidelines from Hair et al. (2019). PLS is a well-known method for constructing predictive models when the factors are many and highly collinear (Tobias, n.d.). According to Hair et al. (2019). PLS is the structural equation model (SEM) technique in which it assesses the reliability and validity of the measures of theoretical constructs and estimates the relationships among these constructs simultaneously. The advantages of PLS include minimal restrictions on measurement scales, sample size, and residual distributions (Chin et al., 2003), Thus, PLS examines the inner and outer models, as well as the hypotheses in order to obtain the results (Hussein, 2015) - see Figure 1.

\section{Results and Discussion}

\section{Respondents' Demographic}

In this study, the respondents' demographics of the current research comprise gender, age group, marital status, educational background, occupation, income, and expenditure as represented in Table 1.

Table 1 shows that the respondents were dominated by those between the age group of $21-30(64 \%), 31-40(21 \%)$, under $20(2 \%)$, and over $40(13 \%)$. In terms of educational background, the majority of respondents are dominated by bachelor degree $(58 \%)$. followed by master degree $(31 \%)$ and doctoral degree $(5 \%)$, while $6 \%$ are from senior high school and diploma.

Table 1 also shows that the respondents' occupation. The majority of the respondents $(33 \%)$ was students at university, and followed by private employees $(31 \%)$, entrerpreneurs $(13 \%)$, civil servants $(8 \%)$. housewife (8\%), and other occupations $(7 \%)$.

Based on the description in Table 1, over half of the respondents $(70 \%)$ are in the income group of less than IDR 5 million. The remaining 30\% of the surveyed respondents earned IDR 6 million to more than IDR 16 million. In terms of expenditure, most of the respondents spend less than IDR 4 million (75\%), followed by spending between IDR 5 million to more than IDR 8 million $(25 \%)$. 
Tabel 1. The Respondents Demographic

\begin{tabular}{|c|c|c|}
\hline Respondents' Characteristic & Description & Percentage $(\%)$ \\
\hline \multirow{2}{*}{ Gender } & Male & $52 \%$ \\
\hline & Female & $48 \%$ \\
\hline \multirow{4}{*}{ Age } & Under 20 & $2 \%$ \\
\hline & $21-30$ & $64 \%$ \\
\hline & $31-40$ & $21 \%$ \\
\hline & 41-Above 50 & $13 \%$ \\
\hline \multirow{5}{*}{ Educational Background } & Senior high school & $4 \%$ \\
\hline & Diploma & $2 \%$ \\
\hline & Bachelor & $58 \%$ \\
\hline & Master & $31 \%$ \\
\hline & $\mathrm{PhD}$ & $5 \%$ \\
\hline \multirow{6}{*}{ Occupation } & Civil Servants & $8 \%$ \\
\hline & Private Employees & $31 \%$ \\
\hline & Enterpreneur & $13 \%$ \\
\hline & Student & $33 \%$ \\
\hline & Housewife & $8 \%$ \\
\hline & Others & $7 \%$ \\
\hline \multirow{4}{*}{ Income } & Less than 3 million & $28 \%$ \\
\hline & 3-5 million & $42 \%$ \\
\hline & 6-9 million & $18 \%$ \\
\hline & 10 - more than 16 million & $12 \%$ \\
\hline \multirow{4}{*}{ Expenditure } & less than 2 million & $25 \%$ \\
\hline & 2-4 million & $50 \%$ \\
\hline & 5-7 million & $17 \%$ \\
\hline & more than 8 million & $8 \%$ \\
\hline
\end{tabular}

Source: (Survey, 2020)

\section{Measurement Model Assessment}

In the first step of measurement model assessment (outer modeling), the study used the test of convergent validity and discriminant validity which are used to assess the measurement model. During the test of convergent validity, the factor loading (FL), Cronbach's alpha (Cronbach $\alpha$ ), composite reliability (CR), and average variance extracted (AVE) were taken into the consideration in this study (Hair et al., 2019).

Tabel 2. The Results of the Measurement Model

\begin{tabular}{lllccc}
\hline Constructs & Items & FL & Cronbach's $\boldsymbol{\alpha}$ & CR & AVE \\
\hline & PU1 & 0.9158 & & & \\
& PU2 & 0.9452 & & & \\
Perceived usefulness (PU) & PU3 & 0.9255 & 0.9715 & 0.9768 & 0.8755 \\
& PU4 & 0.9260 & & & \\
& PU5 & 0.9452 & & & \\
& PU6 & 0.9556 & & & \\
& PEOU1 & 0.9187 & & & \\
& PEOU2 & 0.8918 & & & \\
& PEOU3 & 0.8984 & 0.9657 & \\
Perceived ease of use (PEOU) & PEOU4 & 0.9299 & & & \\
& PEOU5 & 0.8957 & & & \\
& PEOU6 & 0.9128 & & & \\
& BI1 & 0.9065 & & & \\
Behavioral Intention (BI) & BI2 & 0.9297 & \multirow{2}{*}{0.9446} & & \\
& BI3 & 0.9418 & & & \\
& BI4 & 0.9257 & & & \\
\hline
\end{tabular}

Source: (Data processing) 
Based on the results presented in Table 2, it shows that FL for all items is greater than 0.70 which is recommended value by Hair et al. (2019) and it indicates that indicator loading above 0.708 explains more than $50 \%$ of the indicator's variance providing acceptable item reliability.

The convergent validity was also evaluated through CR and Cronbach's $\alpha$, and all variables are higher than 0.70, which meets the criteria of Hair et al. (2009). In terms of AVE requirement Fornell \& Larcker (1981), Hair et al. (2009), Hair et al. (2019) suggested that AVE should exceed 0.50 . In the current study, AVEs have a minimum value of 0.50 in the range between 0.8245 and 0.8755 which meets the benchmark proposed by Fornell \& Larcker (1981), Hair et al. (2009), Hair et al. (2019).

In the second step of measurement model assessment, the discriminant validity was assessed by using cross-loading analysis and AVE. Table 3 presents that AVE is higher than the correlation between the variables for all cases which are recommended by Fornell \& Larcker (1981). It is suggesting that the required discriminant validity has been achieved in this study.

Based on all these results, it confirms that the measurement model has adequate convergent validity and discriminant validity and can be used to examine the structural model.

Table 3. The Results of Discriminant Validity

\begin{tabular}{lccc}
\hline & BI & PEOU & PU \\
\hline BI & 0.9260 & & \\
PEOU & 0.7645 & 0.9080 & 0.9357 \\
PU & 0.8166 & 0.9012 & \\
\hline
\end{tabular}

Notes: $\mathrm{BI}=$ behavioral intention; $\mathrm{PEOU}=$ perceived ease of use; $\mathrm{PU}=$ perceived usefulness; The diagonal elements represent the square root of AVE (Average Variance Extracted).

Source: (Data processing)

\section{Structural Model Assessment}

In this study, before hypothesis testing, the goodness of the structural model (inner modeling) was analyzed by examining the $R$-square $\left(R^{2}\right)$ and the predictive relevance $\left(Q^{2}\right)$ (Hair et al., 2019). $R^{2}$ is the assessment of the model predictive accuracy and higher $\mathrm{R}^{2}$ representing a higher level of predictive accuracy (Hair et al., 2011; Hair et al., 2019).

Table 4 shows that $\mathrm{R}^{2}$ value for PU and BI to use Islamic crowdfunding platform are 0.8121 and 0.6712 , respectively. The $\mathrm{R}^{2}$ value mean that $81.21 \%$ of the variance in PU and BI to use Islamic crowdfunding platform can be explained by PEOU and PU. Some researchers (Abror \& Hudayati, 2020; Kholid, 2019; Thaker, 2018) interpret the $\mathrm{R}^{2}$ value as a measure to assess model's predictive power.

Additionally, the predictive relevance $\left(\mathrm{Q}^{2}\right)$ is used to assess the PLS path model's predictive accuracy based on the blindfolding procedure (Hair et al., 2019; Henseler et al., 2009). Hair et al. (2011) and Hair et al. (2019) suggested that $Q^{2}$ value should be larger than zero, as it indicates that the exogenous constructs have predictive relevance for the endogenous construct. For this this study, Table 4 shows that the $\mathrm{Q}^{2}$ of $\mathrm{PU}$ and $\mathrm{BI}$ to use the Islamic crowdfunding platform model are 0.7067 and 0.5628 , respectively. Thus, it can be concluded that the research model has good predictive relevance because the $\mathrm{Q}^{2}$ value are larger than zero.

Tabel 4. R-Square Value and Predictive Relevance Value

\begin{tabular}{lcc}
\hline Variable & R-square $\mathbf{( R}^{\mathbf{2}} \mathbf{~}$ & Predictive Relevance $\mathbf{( Q}^{\mathbf{2}} \mathbf{)}$ \\
\hline PU & 0.8121 & 0.7067 \\
BI & 0.6712 & 0.5628 \\
\hline
\end{tabular}

Notes: Behavioral Intention (BI) and Perceived Usefulness (PU) are dependent variables

Source: (Data processing)

After conducting the test of $\mathrm{R}^{2}$ and $\mathrm{Q}^{2}$, the study calculates the path coefficient of the structural model and then performs bootstrapping procedure in order to assess the statistical significance of the path coefficients (re-sampling $=500)$. The hypotheses $(\mathrm{H} 1-\mathrm{H} 3)$ are assessed in 
Figure 1 at the significance level of $0.10(10 \%), 0.05(5 \%)$, and $0.01(1 \%)$. Results are shown in Table 5, PU has a positive and significant relationship with BI to use Islamic crowdfunding platform with $\beta=0.6796, p<0.01$. In addition, PEOU has a positive and significant relationship (direct effect) with PU to use Islamic crowdfunding platform with $\beta=0.9012, p<0.01$, and thus supports H1, and H3. On the contrary, PEOU $(\beta=0.1521, \mathrm{p}>0.10)$ has an insignificant effect on BI to use Islamic crowdfunding platform and rejects H2. Therefore, two out of three hypotheses are accepted (see Table 5 and Figure 2).

Table 5. The Results of Structural Model

\begin{tabular}{cllccl}
\hline Hypothesis & Relationship & \multicolumn{1}{c}{ Beta $(\boldsymbol{\beta})$} & T-Statistics & $p$-value & \multicolumn{1}{c}{ Remarks } \\
\hline$H 1$ & PU $\rightarrow$ BI & $0.6796^{* * *}$ & 4.2804 & 0.0000 & Supported \\
H2 & PEOU $\rightarrow$ BI & 0.1521 & 0.9245 & 0.3557 & Unsupported \\
H3 & PEU $\rightarrow$ PU & $0.9012^{* * *}$ & 30.2910 & 0.0000 & Supported \\
\hline
\end{tabular}

Note: Significant level; $* * * p<0.01 ; * * p<0.05 ; * p<0.10$

Source: (Data processing)

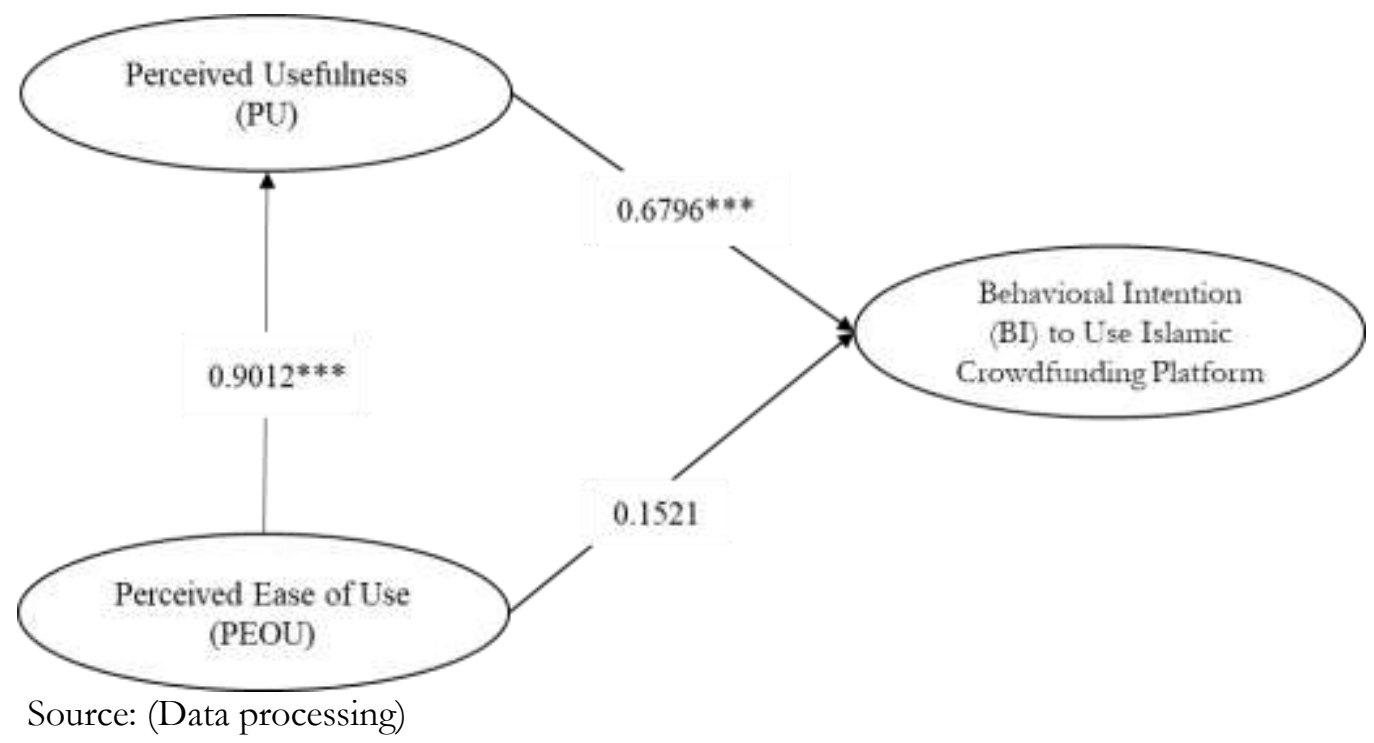

Figure 2. The Results of Structural Model

\section{Discussion}

The major objective of the study is to test empirically the determining factors of the behavioral intention of crowdfunders to use the Islamic crowdfunding platform as an alternative source of investment during the period of Covid-19 pandemic in Indonesia. The results show the good measurement and structural model, a support the two out of three hypotheses.

The path between PU and BI to use Islamic crowdfunding platform is significant and positive $(\phi<0.01$ and $\beta=0.6796)$. The result is consistent with the work of Abbasi et al. (2011), Cheng et al. (2006), Davis (1989), Ratri (2016), Riza \& Hafizi (2019), Thaker (2018). It can be explained that the crowdfunders believe that the Islamic crowdfunding platform will provide better performance, productivity, and effectiveness especially for investing in the online platform and it will help MSMEs affected by Covid-19 with the shariah financial sevices. This model is expected to create a positive perception toward the crowdfunders in investing and helping to provide an alternative source of financing for MSMEs in times of Covid-19 pandemic in Indonesia.

On the other hand, the path between PEOU and BI to use Islamic crowdfunding platform shows an insignificant relationship $(p>0.10$ and $\beta=0.1521)$. This finding is also similar to the findings by Ratri (2016). Even though the relationship has no significant effect, the crowdfunders have a positive intention to use the online platform and they feel easy accessibility, flexibility, and controllability. In addition to that, the crowdfunders believe that the Islamic crowdfunding 
platform will be easy to master. Especially, the model provides the shariah financing services for MSMEs in times of Covid-19 pandemic in Indonesia.

Meanwhile, the association between the PEOU and PU is positively significant $(p<0.01$ and $\beta=0.9012$ ). The researcher found that the relationship of these variables is the main variable influences an individual intention to use the Islamic crowdfunding platform. The results are in accordance with the studies of Riza \& Hafizi (2019) and Thaker (2018). They mentioned that the easier the system to be used, the more useful it was perceived to be. Thus, the Islamic crowdfunding platform may need to have features that are useful to the user particularly the crowdfunders who want to invest their funds in the online platform and support MSMEs affected by Covid-19 in Indonesia.

\section{Conclusion}

This study has empirically tested the behavioral intention of crowdfunders in using Islamic crowdfunding model by applying the TAM approach and the analysis is conducted using PLS (partial least squares). The results show the good model and it confirms the acceptance of two out of three hypotheses ( $\mathrm{H} 1$ and $\mathrm{H} 3$ are accepted, while $\mathrm{H} 2$ is rejected). In other words, all the paths show a significant positive association with behavioral intention, except for the perceived ease of use on perceived usefulness. Therefore, the Islamic crowdfunding platform is the platform that can be potentially adopted for crowdfunders in investment activities and participation in providing an alternative source of financing for the MSMEs in Indonesia especially during the crisis like Covid19. Furthermore, the model is expected to help the economy recovery and to minimize the damages of Covid-19 on MSMEs in Indonesia.

Based on the result of study, the following recommendations are made. Firstly, for Islamic FinTech companies in Indonesia, they should promote high-quality projects to the crowdfunders in making a well-informed decision before investing fund in the online platform. Additionally, to enhance the intention of crowdfunders to use the Islamic corwdfunding platform, Islamic FinTech industries also should minimize the risk exposure for online platform by improving security of virtual transaction as suggested by Thaker (2018). Besides that, Islamic FinTech also should provide the online platform more secure for all privacy of users. The model could use the Artificial Intelligence (AI) and Natural Language Process (NLP) to make the system more effective and transparent as recommended by Haider \& Khan (2020).

Secondly, this Islamic crowdfunding platform also brings benefits to MSMEs because the model will provide financial support for MSMEs apart from banking particularly during the Covid19 pandemic. Thus, the Islamic FinTech companies as a crowdfunding operator should be promote by video presentation, infographic, and other forms of publication to attract the crowdfunders to participate in the financing service programme for MSMEs affected by Covid-19.

Lastly, the study will contribute to the existing literature in the areas of Islamic FinTech especially on the factors influencing behavioral intentions to use the Islamic crowdfunding platform in Indonesia. However, the sample size of the study becomes an obvious limitation. The sample size of the study should be added for future study. In addition to that, future research also can be conducted by incorporating other factors such as social media, riskiness, and others.

\section{Acknowledgements}

I would like to thank to LPDP (Lembaga Pengelola Dana Pendidikan). My master's study in Islamic Economic Science Program, Faculty of Economic and Business, Airlangga University, is fully funded by LPDP Scholarships.

\section{Author Contributions}

Conceptualization: Sulaeman

Data curation: Sulaeman

Formal analysis: Sulaeman

Investigation: Sulaeman 
Methodology: Sulaeman

Project administration: Sulaeman

Supervision: Sulaeman

Validation: Sulaeman

Visualization: Sulaeman

Writing - original draft: Sulaeman

Writing - review \& editing: Sulaeman

\section{References}

Abbasi, S., Chandio, M. H. ., Soomro, A. ., \& Shah, F. (2011). Social influence, voluntariness, experience and the internet acceptance: An extension of technology acceptance model within a south-Asian country context. Journal of Enterprise Information Management, 24(1), 30-52. https://doi.org/10.1108/17410391111097410

Abror, A., \& Hudayati, A. (2020). The effect of distributive justice on intention to pay zakat through zakat institutions using affective and cognitive trust as intervening variables. Jurnal Ekonomi \& Keuangan Islam, 6(1), 24-33. https://doi.org/10.20885/jeki.vol6.iss1.art3

Achsien, I. H., \& Purnamasari, D. L. (2016). Islamic crowd-funding as the next financial innovation in Islamic finance: Potential and anticipated regulation in Indonesia. European Journal of Islamic Finance, (5), 1-11. https://doi.org/10.13135/2421-2172/1771

Aulia, M., Yustiardhi, A. F., \& Permatasari, R. O. (2020). An overview of Indonesian regulatory framework on Islamic financial technology (fintech). Jurnal Ekonomi \& Kenangan Islam, 6(1), 64-75. https://doi.org/10.20885/jeki.vol6.iss1.art7

Bank Indonesia. Peraturan Bank Indonesia (PBI) No.19/12/PBI/ 2017 tentang Penyelenggaraan Teknologi Finansial. Bank Indonesia. Retrieved from https://peraturan.bpk.go.id

Belleflamme, P., Lambert, T., \& Schwienbacher, A. (2014). Crowdfunding: Tapping the right crowd. Journal of Business Venturing, 29(5), 585-609. https://doi.org/10.1016/j.jbusvent.2013.07.003

Burhan, A. (2020, April 15). Dampak Covid-19 terhadap kinerja BMT. Republika. Retrieved from https://www.republika.co.id/

Chamani, A., Anshory, A., Hudaefi, F. A., Junari, U. L., \& Zaenal, M. H. (2020). The role of zakat institution in preventing Covid-19. Retrieved March, 25, 2020, from https://www.puskasbaznas.com

Chen, S.-C., Li, S.-H., \& Li, C.-Y. (2011). Recent related research in technology acceptance model: A literature review. Australian Journal of Business and Management Research, 1(9), 124 127. Retrieved from http://ajbmr.com/articlepdf/AJBMR_19_04i1n9a14.pdf

Cheng, T., Lam, D. Y. C., \& Yeung, A. C. L. (2006). Adoption of internet banking: An empirical study in Hong Kong. Decision Support Systems, 24(3), 1558-1572. https://doi.org/10.1016/j.dss.2006.01.002

Chin, W. W., Marcolin, B. L., \& Newsted, P. R. (2003). A partial least squares latent variable modeling approach for measuring interaction effects: Results from a Monte Carlo simulation study and an electronic-mail emotion/adoption study. Information Systems Research, 14(2), 189-217. https://doi.org/10.1287/isre.14.2.189.16018

Darmansyah, D., Fianto, B. A., Hendratmi, A., \& Aziz, P. F. (2020). Factors determining behavioral intentions to use Islamic financial technology. Journal of Islamic Marketing. https://doi.org/10.1108/JIMA-12-2019-0252

Davis, F. D. (1989). Perceived usefulness, perceived ease of use, and user acceptance of information technology. MIS Quarterly, 13(3), 319. https://doi.org/10.2307/249008 
Davis, F. D. (1993). User acceptance of information technology: System characteristics, user perception and behavioral impacts. International Journal of Man-Machine Studies, (38), 475487. https://doi.org/10.1007/SpringerReference_70955

Dewan Syariah Nasional. Fatwa Dewan Syariah Nasional-Majelis Ulama Indonesia Nomor 117/DSNMUI/II/ 2018 tentang Layanan Pembiayaan Berbasis Teknologi Informasi Berdasarkan Prinsip Syariah. , Pub. L. No. 117/DSN-MUI/II/2018, 1 (2018). Retrieved from https://dsnmui.or.id/kategori/fatwa/page/2/

Dresner, S. (2014). Crowdfunding: A Guide to Raising Capital on the Internet. New York, NY: John Wiley \& Sons.

Fornell, C., \& Larcker, D. F. (1981). Evaluating structural equation models with unobservable variables and measurement error. Journal of Marketing Research, 18(1), 39-50. https://doi.org/10.1177/002224378101800104

Haider, M., \& Khan, S. (2020). An artificial intelligence and NLP based Islamic FinTech Model Combining Zakat and Qardh-Al-Hasan for countering the adverse impact of COVID 19 on SMEs and ndividuals. International Journal of Economics \& Business Administration, 8(2) 351-364. https://doi.org/10.35808/ijeba/466

Hair, J.F., Ringle, C. M., \& Sarstedt, M. (2011). PLS-SEM: Indeed a silver bullet. Journal of Marketing Theory and Practice, 19(2), 139-152. https://doi.org/10.2753/MTP1069$\underline{6679190202}$

Hair, Joseph F., Black, W. C., Babin, B. J., \& Anderson, R. E. (2009). Multivariate Data Analysis (7th ed). Upper Saddle River, NJ: Pearson Prentice Hall.

Hair, Joseph F, Risher, J. J., Sarstedt, M., \& Ringle, C. M. (2019). When to use and how to report the results of PLS-SEM. European Business Review, 31(1), 2-24. https://doi.org/10.1108/EBR-11-2018-0203

Harahap, B. A., Idham, P. B., Kusuma, A. C. M., \& Rakhman, R. N. (2017). Perkembangan financial technology terkait central bank digital currency (cbdc) terhadap transmisi kebijakan moneter dan makroekonomi. Working Paper, 2, 1-80. Retrieved from http://publication-bi.org/repec/idn/wpaper/WP022017.pdf

Henseler, J., Ringle, C. M., \& Sinkovics, R. R. (2009).The use of partial least squares path modeling in international marketing. New Challenges to International Marketing, 20, 277-319. https://doi.org/10.1108/S1474-7979(2009)0000020014

Hidajat, T. (2019). Unethical practices peer-to-peer lending in Indonesia. Journal of Financial Crime, 27(1), 274-282. https://doi.org/10.1108/JFC-02-2019-0028

Hua, X., Huang, Y., \& Zheng, Y. (2019). Current practices, new insights, and emerging trends of financial technologies. Industrial Management \& Data Systems, 119(7), 1401-1410. https://doi.org/10.1108/IMDS-08-2019-0431

Hudaefi, F. A., Beik, I. S., Zaenal, M. H., Choirin, M., Farchatunnisa, H., \& Junari, U. L. (2020). How does zakat institution respond to fintech $\square$ ? Evidence from BAZNAS Indonesia. IJZIP: International Journal of Zakat and Islamic Philanthropy, 2(1), 33-40. Retrieved from http://journal.zakatkedah.com.my/wp-content/uploads/2020/03/Vol2_1_4_20.pdf

Huei, C. T., Suet Cheng, L., Chee Seong, L., Aye Khin, A., \& Ling Leh Bin, R. (2018). Preliminary study on consumer attitude towards FinTech oroducts and services in Malaysia. International Journal of Engineering \& Technology, 7(2.29), 166. https://doi.org/10.14419/ijet.v7i2.29.13310

Hussein, A. S. (2015). Modul Ajar: Penelitian Bisnis dan Manajemen Menggunakan Partial Least Squares (PLS) dengan smartPLS 3.0. Retrieved from https://www.researchgate.net/file.PostFileLoader.html?id=5786f4c94048544b3332e123 
\&assetKey=AS:383572759334914@1468462280965

Internet World Stats. (2020). Internet World Stats Usage and Population Statistics. Retrieved from https://www.internetworldstats.com/stats3.htm\#asia

Kementerian Koperasi dan UKM. (2018). Perkembangan Data Usaha Mikro Kecil, Menengah (UMKM) dan Usaha Besar (UB) Tahun 2017-2018. Kementerian Koperasi dan UKM. Retrieved from http://www.depkop.go.id/uploads/laporan

Kholid, M. N. (2019). Determinants of intention to use Islamic mobile banking: Evidence from millennial generation. Jurnal Ekonomi \& Keuangan Islam, 5(2), 53-62. https://doi.org/10.20885/jeki.vol5.iss2.art2

Majid, R. (2018). Inovasi skema investasi modal ventura syariah menuju terciptanya UMKM berkelanjutan di era digital. FREKS Kategori Muda Sektor IKNB Syariah, 1-20. Retrieved from https:/ / risetsyariah.ojk.go.id/freks/

Marzban, S., Asutay, M., \& Boseli, A. (2014). Shariah-compliant crowd funding: An efficient framework for entrepreneurship development in Islamic CSR and sustainable development in islamic banking in Malaysia view project mathematic modeling for risksharing contracts view project. Harvard Islamic Finance Forum, 2, 272. https://doi.org/10.13140/RG.2.1.2696.1760

Mollick, E. (2014). The dynamics of crowdfunding: An exploratory study. Journal of Business Venturing, 29(1), 1-16. https://doi.org/10.1016/j.jbusvent.2013.06.005

Mukhlisin, M., Ascarya, Pasumah, B. T., Antonio, M. S., Yasid, M., Mulyana, R., \& Tamanni, L. (2020). Tujub paket kebijkan ekonomi dan keuangan syariah mengatasi dampak krisis Covid-19. Bogor. Retrieved from http://mysharing.co/tujuh-paket-ekonomi-dan-keuangan-syariahmengatasi-dampak-krisis-covid-19/

Otoritas Jasa Keuangan. Peraturan Otoritas Jasa Keuanagan Nomor 77/POJK.01/2016 Tentang Layanan Pinjam Meminjam Uang Berbasis Teknologi Informasi, Otoritas Jasa Keuangan Republik Indonesia. Retrieved from https://www.ojk.go.id/id/regulasi/Pages/POJKtentang-Layanan-Pinjam-Meminjam-Uang-Berbasis-Teknologi-Informasi.aspx

Ramos, J. (2015). crowdfunding and the role of managers in ensuring the sustainability of crowdfunding platforms third main title line third line. JRC Scientific and Policy Reports. European Commission. https://doi.org/10.13140/RG.2.1.3925.6480

Ratri, S. M. (2016). Analisis faktor-faktor yang memengaruhi penggunaan e-learning moodle oleh guru SMK Negeri 2 Yogyakarta dengan pendekatan Technology Acceptance Model (TAM). Journal Elektronika Pendidikan Teknik Informatika, 5(4), 1-9. Retrieved from http://journal.student.uny.ac.id/ojs/index.php/pti/article/view/4700/pdf

Raza, S. A., Shah, N., \& Ali, M. (2019). Acceptance of mobile banking in Islamic banks: Evidence from modified UTAUT model. Journal of Islamic Marketing, 10(1), 357-376. https://doi.org/10.1108/JIMA-04-2017-0038

Riza, A. F., \& Hafizi, M. R. (2019). Customers attitude toward Islamic mobile banking in Indonesia: Implementation of TAM. Asian Journal of Islamic Management (AJIM), 1(2), 7584. https://doi.org/10.20885/ajim.vol1.iss2.art1

Sangwan, V., Harshita, H., Prakash, P., \& Singh, S. (2019). Financial technology: A review of extant literature. Studies in Economics and Finance, 37(1), 71-88. https://doi.org/10.1108/SEF-07-2019-0270

Suhaili, N. A., \& Palil, M. R. (2016). Crowdfunding: A collaborative waqf Based Internet Platform. International Journal of Business, Economics and Law, 11(5), 41-46. Retrieved from https://www.researchgate.net/publication/318200553

Tamimi, A., \& Ahmad, M. (2020). Online repatronage intention: An online system usage and 
purchase experiance perspective. BITAR A International Journal of Civilizational and Human Science, 3(1), 001-009. Retrieved from

http://bitarajournal.com/index.php/bitarajournal/article/view/97

Thaker, M. A. B. M. T. (2018). Factors influencing the adoption of the crowdfunding-waqf model (CWM) in the waqf land development. Journal of Islamic Marketing, 9(3), 578-597. https://doi.org/10.1108/JIMA-05-2016-0043

Tobias, R. D. (n.d.). An Introduction to Partial Least Squares Regression. Carry, NC. Retrieved from https://www.semanticscholar.org/paper/An-Introduction-to-Partial-Least-SquaresRegression-Tobias/be6e7c9bba61584ac5bb4e4f77611095abb2037a

Venkatesh, V., \& Davis, F. D. (2000). Theoretical extension of the Technology Acceptance Model: Four longitudinal field studies. Management Science, 46(2), 186-204. https://doi.org/10.1287/mnsc.46.2.186.11926

Victoria, A. O. (2020). Sri Mulyani Sebut Covid-19 Lebih Kompleks dari Krisis 1998 dan 2008. Retrieved April 30, 2020, from https://katadata.co.id/berita/2020/04/07/sri-mulyanisebut-covid-19-lebih-kompleks-dari-krisis-1998-dan-2008 


\section{Appendices}

\section{Appendix 1. Question statements}

\begin{tabular}{|c|c|}
\hline Constructs & Qusetion Statements \\
\hline \multirow{6}{*}{$\begin{array}{l}\text { Perceived } \\
\text { usefulness } \\
\text { (PU) }\end{array}$} & PU1. Using Islamic crowdfunding platform can help me to finish the job more quickly \\
\hline & PU2. Using Islamic crowdfunding platform can improve my performance \\
\hline & PU3. Using Islamic crowdfunding platform can improve my productivity to participate \\
\hline & PU4. Using Islamic crowdfunding platform can increase my effectiveness of business \\
\hline & PU5. Using Islamic crowdfunding platform make my job easier \\
\hline & PU6. Overall, using Islamic crowdfunding platform can helpful and useful \\
\hline \multirow{6}{*}{$\begin{array}{l}\text { Perceived } \\
\text { ease of use } \\
\text { (PEOU) }\end{array}$} & PEOU1. Easy for me to learn Islamic crowdfunding platform \\
\hline & PEOU2. Easy for me to control and operate the Islamic crowdfunding platform \\
\hline & PEOU3. Easy for me to use it when the platform is clear and understandable \\
\hline & PEOU4. I feel Islamic crowdfunding platform flexible to use \\
\hline & PEOU5. Easy for me to become skillful/master the use of Islamic crowdfunding platform \\
\hline & PEOU6. Overall, Islamic crowdfunding platform is easy to use \\
\hline \multirow{4}{*}{$\begin{array}{l}\text { Behavioral } \\
\text { Intention } \\
\text { (BI) }\end{array}$} & $\begin{array}{l}\text { BI1. I have the intention of using Islamic crowdfunding platform for investment because } \\
\text { it is easy to use and can help MSMEs affected by Covid-19 }\end{array}$ \\
\hline & $\begin{array}{l}\text { BI2. I will use the Islamic crowdfunding platform as my priority platform for investment } \\
\text { because people in my enviroment support using it and can help MSMEs affected by Covid-19 }\end{array}$ \\
\hline & $\begin{array}{l}\text { BI3. I will use the Islamic crowdfunding platform in the future because it is effective and } \\
\text { efficient as well as can help MSMEs affected by Covid-19 }\end{array}$ \\
\hline & $\begin{array}{l}\text { BI4. I will suggest someone else in my environment to use the Islamic crowdfunding } \\
\text { platform because it can help MSMEs affected by Covid- } 19\end{array}$ \\
\hline
\end{tabular}

